
\title{
is Research Square \\ Validity and Reliability of the Persian Version of the Patient Readiness to Engage in Health Information Technology
}

\section{Reza Safdari}

Tehran University of Medical Sciences

Ping Yu

University of Wollongong

Sahar khenarinezhad

Tehran University of Medical Sciences

Ehsan Ghazanfari Savadkoohi

Tehran University of Medical Sciences

Zohreh Javanmard

Tehran University of Medical Sciences

Ala Yousefi

Iran University of Medical Sciences

Saeed Barzegari ( $\boldsymbol{D}$ barz_saeed@yahoo.com )

Mazandaran University of Medical Sciences

\section{Research Article}

Keywords: PRE-HIT, patient readiness; health information technology, psychometric properties, consumer health information, public health

Posted Date: October 12th, 2021

DOI: https://doi.org/10.21203/rs.3.rs-930674/v1

License: (9) (i) This work is licensed under a Creative Commons Attribution 4.0 International License. Read Full License 


\section{Abstract}

\section{Background:}

The patient readiness to engage in health information technology (PRE-HIT) is a conceptually and psychometrically validated questionnaire survey tool to measure willingness of patients with chronic conditions to use health information technology (HIT) resources.

\section{Objectives:}

This study was aimed to translate and validate a health information technology readiness instrument, the PREHIT instrument, in the Persian language.

\section{Methods:}

A rigorous process was followed to translate the PRE-HIT instrument Persian language. The face and content validity was validated by impact score, content validity index (CVI) and content validity ratio (CVR). The instrument was used to measure readiness of 289 patients with chronic diseases to engage with digital health with four point Likert scale. Exploratory factor analysis (EFA) and confirmatory factor analysis (CFA) used to check the validity of structure. The convergent and discriminant validity, and internal reliability was expressed by average variance extracted (AVE), construct reliability (CR), maximum shared squared variance (MSV), average shared square variance (ASV), and Cronbach's alpha coefficient. Independent samples t-test and one-way ANOVA were used respectively to compare the impact of sex, education and computer literacy on the performance of all PRE-HIT factors.

\section{Results:}

Eight factors were extracted: health information needs, computer anxiety, computer/internet experience and expertise, preferred mode of interaction, no news is good news, relationship with doctor, cell phone expertise, and internet privacy concerns. They explained $69 \%$ of the total variance. An acceptable model fit and internal reliability of the instrument was achieved. The survey found that the Iranian patients had high level of cell phone expertise, computer/internet experience, good relationship with doctor, and high level of health information need. They had moderate level of concern about internet privacy and computer anxiety. Compared with men, women had higher level of health information need and more agreed with "no news is good news", conversely men had higher level of cell phone expertise.

\section{Conclusion:}

The Persian version of the PRE-HIT was empirically proved for its validity to assess the level of readiness of patients to engage with digital health.

\section{Introduction}

Plagued by the COVID-19 pandemic, the adoption of digital health is expediting globally. For example, telehealth has been widely adopted to bring essential health care to patients while minimising the risk of direct human-tohuman exposure [1]. In general, there is an increasing recognition of the contribution of digital health for 
improving quality of care, reducing medical errors, [2,3] managing chronic diseases, and improving health service efficiency and reducing cost. Communication over the internet, mobile or computer, between physicians and patients, has many potential benefits [4]. Also, digital health can inform and empower patients to actively engage with planning and managing life style and self-care [5]. However, all these benefits cannot be achieved without consumer readiness [6]; therefore, it is important to understand consumer readiness to engage with digital health [7].

Technology readiness has been conceptualised as the level of willingness, understanding, and skill in using the technology [2, 8]. Assessment of readiness can help designers to design effective digital solutions, i.e., webbased and mobile applications [9]. A range of digital health readiness measurement instruments have been developed (see Table 1). Kayser et al. developed and validated the psychometric property of READHY tool via questionnaire survey with 305 cancer patients (see Table 1). The instrument assesses patients' knowledge and skills, readiness and ability to engage with and benefit from healthcare technologies [7]. Hirani et al. (2017) conceptualized and validated the psychometric property of SUTAQ, the questionnaire survey instrument to predict user's acceptance of telemedicine tools based on their prior experience. SUTAQ also predicts users' believes and behavior with telemedicine tools. Its weakness is a lack of consideration of user's health knowledge and digital skill $[7,10]$. The PERQ includes eight questions that ask patient's internet usage, social support, personal abilities, economic status and self-efficacy in using eHealth applications [11]. However, its conceptual and psychometric validity has not been tested. Norman and Skinner developed the eHEALS instrument to measure consumer eHealth literacy and ability to search, use, and evaluate health resources on the internet. limitations of this instrument includes an inability to directly measure consumers' eHealth skills, and its validity was only tested in the 13-21 year young people with high level use of technology, not in the old adults [12]. Its measurement items need to be revised and further validated [13].

Table 1. Comparison of the published instruments for measuring consumer readiness to adopt to use digital health. 


\begin{tabular}{|c|c|c|c|c|c|}
\hline $\begin{array}{l}\text { Tool, } \\
\text { Author and } \\
\text { Year of } \\
\text { publication }\end{array}$ & Goal & Factors & Items & $\begin{array}{l}\text { Variance } \\
\text { Explained }\end{array}$ & Limitations \\
\hline $\begin{array}{l}\text { PERQ, } \\
\text { Jones et } \\
\text { al, } \\
(2013)\end{array}$ & $\begin{array}{l}\text { Assess } \\
\text { patient } \\
\text { readiness to } \\
\text { use eHealth } \\
\text { tools. }\end{array}$ & $\begin{array}{l}\text { Four factors: Patients' perception } \\
\text { of ( } 1) \text { provision, }(2) \text { their personal } \\
\text { ability and confidence, ( } 3 \text { ) their } \\
\text { interpersonal support, and (4) } \\
\text { relative costs in using the Internet } \\
\text { for health. }\end{array}$ & Nine & $\begin{array}{l}\text { Not } \\
\text { mentioned }\end{array}$ & $\begin{array}{l}\text { Is not a } \\
\text { conceptually } \\
\text { and } \\
\text { psychometrically } \\
\text { validated tool. }\end{array}$ \\
\hline $\begin{array}{l}\text { eHEALAS, } \\
\text { Norman } \\
\text { and } \\
\text { Skinner, } \\
\text { (2006) }\end{array}$ & $\begin{array}{l}\text { Assess user } \\
\text { skill and } \\
\text { knowledge } \\
\text { with digital } \\
\text { solutions. }\end{array}$ & Single-factor instrument & 10 & $56 \%$ & $\begin{array}{l}\text { Can't measure } \\
\text { consumers' } \\
\text { skills directly, } \\
\text { presents a } \\
\text { limitation in } \\
\text { testing with a } \\
\text { population that } \\
\text { has high rates of } \\
\text { information } \\
\text { technology and } \\
\text { older adults. }\end{array}$ \\
\hline $\begin{array}{l}\text { SUTAQ, } \\
\text { Hirani et al, } \\
\text { (2016) }\end{array}$ & $\begin{array}{l}\text { Assess the } \\
\text { acceptance } \\
\text { of } \\
\text { telemedicine } \\
\text { tools }\end{array}$ & $\begin{array}{l}\text { Five factors: perceived benefit, } \\
\text { privacy and discomfort, care } \\
\text { personnel concerns, kit as a } \\
\text { substitution, and satisfaction. }\end{array}$ & 22 & 60.7 & $\begin{array}{l}\text { No considered } \\
\text { user's knowledge } \\
\text { and skills about } \\
\text { information } \\
\text { technologies. }\end{array}$ \\
\hline $\begin{array}{l}\text { READHY, } \\
\text { Kayser et } \\
\text { al, (2019) }\end{array}$ & $\begin{array}{l}\text { Measure } \\
\text { consumer } \\
\text { readiness to } \\
\text { use health } \\
\text { technologies. }\end{array}$ & $\begin{array}{l}\text { Five factors: users' knowledge } \\
\text { and skills ( } 3 \text { items: using } \\
\text { technology to process health } \\
\text { information; understanding of } \\
\text { health concepts and language } \\
\text { ability to actively engage with } \\
\text { digital services); self- } \\
\text { management of disease ( } 2 \text { items: } \\
\text { self-monitoring and insight; skills } \\
\text { and technique acquisition); } \\
\text { perceptions and mindset (4 } \\
\text { items: feel safe and in control; } \\
\text { motivated to engage with digital } \\
\text { services; constructive attitudes } \\
\text { and approaches; emotional } \\
\text { distress); experience with health } \\
\text { technology systems ( } 2 \text { items: } \\
\text { access to digital services that } \\
\text { work; digital services that suit } \\
\text { individual needs); understanding } \\
\text { of the extent to which users feel } \\
\text { supported by relatives, peers, and } \\
\text { health professionals ( } 2 \text { items:, } \\
\text { feeling understood and } \\
\text { supported by health care } \\
\text { providers; social support for } \\
\text { health). }\end{array}$ & 65 & $\begin{array}{l}\text { Not } \\
\text { mentioned }\end{array}$ & $\begin{array}{l}\text { The sample size } \\
\text { of Kayser's study } \\
\text { is not enough. }\end{array}$ \\
\hline $\begin{array}{l}\text { PRE-HIT, } \\
\text { Koopman } \\
\text { et al, } \\
(2014)\end{array}$ & $\begin{array}{l}\text { Measure } \\
\text { patient } \\
\text { readiness to } \\
\text { interact with }\end{array}$ & $\begin{array}{l}\text { Eight factors: health information } \\
\text { need, computer anxiety, } \\
\text { computer/ internet experience, } \\
\text { and expertise, preferred mode of } \\
\text { interaction, no News is good }\end{array}$ & 28 & $\begin{array}{l}\text { Not } \\
\text { mentioned }\end{array}$ & $\begin{array}{l}\text { The lack of } \\
\text { certain scores to } \\
\text { predict use and } \\
\text { non-use of } \\
\text { technology. }\end{array}$ \\
\hline
\end{tabular}


health news, relationship with doctor,

technologies. cell phone expertise, and internet

privacy concerns.

PERQ: patient eHealth readiness questionnaire; eHEALS: eHealth literacy scale; SUTAQ: service user technology acceptability questionnaire; READHY: readiness and enablement index for health technology; PRE-HIT: patient readiness to engage in health internet technology.

The PRE-HIT is a conceptually and psychometrically validated questionnaire survey tool that is built upon the eHEALS to measure willingness of patients with chronic conditions to use health information technology (HIT) resources. The instrument has 28 items that are grouped into 8 factors: health information need (HIN), computer anxiety (CA), computer/internet experience and expertise (CIEE), preferred mode of interaction (PMI), no news is good news (NNGN), relationship with doctor (RWD), cell phone expertise (CPE), and internet privacy concerns (IPC) (see Table 2). It uses a 4-point Likert scale to measure each item. The test score for the PRE-HIT test ranges from the lowest of 28 to the highest of 112. The weakness of the instrument is a lack of clear indicator to predict use or non-use of HIT [9].

Table 2. Definition of the PREHIT factors

\begin{tabular}{|c|c|c|}
\hline Factor & Items & Definition \\
\hline $\begin{array}{l}\text { Health Information } \\
\text { Need (HIN) }\end{array}$ & 5 & $\begin{array}{l}\text { A person's recognition that own knowledge is inadequate to satisfy the } \\
\text { person's health goal within a certain context/situation at a specific point in } \\
\text { the time (Ormandy, 2011). }\end{array}$ \\
\hline $\begin{array}{l}\text { Computer Anxiety } \\
\text { (CA) }\end{array}$ & 4 & $\begin{array}{l}\text { A person's fear of inability to use computer technology or may cause } \\
\text { negative damage as the result of computer usage (Marcoulides, 1989). }\end{array}$ \\
\hline $\begin{array}{l}\text { Computer/Internet } \\
\text { Experience, } \\
\text { Expertise (CIEE) }\end{array}$ & 4 & $\begin{array}{l}\text { Ability of a person to resolve computer/internet usage problems that they } \\
\text { might run into (Koopman et al., 2014). }\end{array}$ \\
\hline $\begin{array}{l}\text { Preferred Mode of } \\
\text { Interaction (PMI) }\end{array}$ & 5 & $\begin{array}{l}\text { Preferred model of contact with doctor, looking up health concerns, and } \\
\text { trusted source of health information (Koopman et al., 2014). }\end{array}$ \\
\hline $\begin{array}{l}\text { No News is Good } \\
\text { News (NNGN) }\end{array}$ & 3 & $\begin{array}{l}\text { Seeking information on the internet could lead a person to encounter more } \\
\text { information than they needed, and some of that information could be } \\
\text { distressing (Koopman et al., 2014). }\end{array}$ \\
\hline $\begin{array}{l}\text { Relationship with } \\
\text { Doctor (RD) }\end{array}$ & 3 & $\begin{array}{l}\text { It refers to a person's trust with physicians as a source of health information } \\
\text { and to handle the person's health (Koopman et al., 2014). }\end{array}$ \\
\hline $\begin{array}{l}\text { Cell Phone } \\
\text { Expertise (CPE) }\end{array}$ & 2 & Going online or text people using a cell phone (Koopman et al., 2014). \\
\hline $\begin{array}{l}\text { Internet Privacy } \\
\text { Concern (IPC) }\end{array}$ & 2 & $\begin{array}{l}\text { Concern about own information transmitted over the internet, which may be } \\
\text { acquired by unauthorized third party (Koopman et al., 2014). }\end{array}$ \\
\hline
\end{tabular}

Not limited to examining patients' eHealth literacy, i.e., computer and internet literacy, media literacy, and desire to search for information, the PRE-HIT also covers broader factors that may influence patients' decision to adopt digital health, i.e., information needs, privacy consideration, IT usage experience, information source, and 
preferred interaction and motivation method, etc. [9]. In comparison with the other similar instruments, we believe that PRE-HIT is the most comprehensive and useful instrument for examining patients' readiness to engaging with digital health.

Objective: This study aims to translate, implement, and validate the Persian version of the PRE-HIT instrument.

\section{Methods}

This research was conducted in three steps. First, the original PRE-HIT instrument was translated into Persian version. Then a cross-sectional questionnaire survey was conducted to collect empirical data from the patients using the Persian version of the PRE-HIT instrument. In Step 3, exploratory and confirmatory factor analysis were conducted to test the structural validity of the instrument.

\section{Step 1. Translation of the PRE-HIT instrument into the Persian version}

The translation task was completed in three sub-steps: forward translation, face and content validation, and back translation.

\section{Forward translation}

At first, items were translated by one translator, a specialist in digital health. Translation considered crosscultural and conceptual equivalence rather than linguistic equivalence for words and phrases to ensure the translated version is concise, simple and fit with Persian language and culture.

\section{Face and content validity}

The expert panel is consisted of four faculty members; two from nursing faculty, one expert in health information management and one from medical informatics. All were familiar with psychometric studies. The panel evaluated the face validity and content validity of the Persian version of the PRE-HIT instrument both qualitatively and quantitatively. Qualitative face validity was assessed by identification of problems and ambiguity in translation, and time required to answer a question. The suggestions of every expert was taken to change words to improve clarity or modify sentences to correct grammar error, or to simplify the expression without losing meaning, or using more appropriate words. Quantitative face validity was assessed using the Impact Score, which was calculated by the formula of frequencyx importance for each item. The experts ranked each item on a 5 point Likert Scale ranging from very important (Score 5) to least important (Score 1). Frequency referred to the percentage of experts who gave an item a score of 4 or 5 . Importance referred to the mean score of each item [14]. An item would be kept if its Impact Score was larger than or equal to 1.5. Quantitative content validity was evaluated by content validity index (CVI) and content validity ratio (CVR). We used the CVI to examine the relevance of each item with the PRE-HIT construct. The expert panel used a 4-point Likert Sale to rate an item ( $1=$ not relevant, $2=$ somewhat relevant, $3=$ quite relevant, $4=$ highly relevant). $\mathrm{CVI}$ score was calculated by the following formula. Items with the CVI score greater than or equal to 0.79 were retained [15].

CVI= number of experts giving a rating of "highly relevant" for an item / total number of experts 
The necessity of the items in the PRE-HIT construct was calculated by the Lawshe test [16]. For this, the expert panel scored an item by 3-point Likert Scale, ranging from essential, useful but not essential, and not necessary. The CVR score was calculated by the following formula. Items with the CVR greater than or equal to 0.49 were retained [15].

$C V R=(N e-N / 2) /(N / 2)$

Where Ne is the number of experts identifying an item as "essential" and $\mathrm{N}$ is the total number of experts.

No cross-cultural and conceptual problems were found. All items achieved the impact scores and all items were equal to or greater than 1.5 , the CVI and CVR scores above 0.79 and 0.49 , respectively; therefore, their face and content validity were proved.

\section{Back-translation}

The Persian version of the questionnaire was translated back to English by an independent translator, who does not know the questionnaire. The translator was an expert in Health Informatics. Attention was paid to conceptual and cross-cultural equivalence. Afterwards, the translator and the research team discussed the English translation and reached agreement on its validity.

\section{Step 2. Cross-sectional questionnaire survey}

\section{The design of the questionnaire}

The questionnaire was comprised of two parts. The first part asked questions about demographic characteristics such as age, sex, level of education, and ownership of the International Computer Driving Licence (ICDL). The second part contained the 4-point Likert Scale questions asking about the PREHIT items.

\section{Sample size calculation}

Because factor analysis (FA) would be applied to investigate the psychometric properties of the PRE-HIT instrument. For valid FA, 5 to 10 samples are required to address a question item [17]. As the PRE-HIT has 28 items, 280 questionnaire responses were required.

\section{Study population}

\section{Inclusion and exclusion criteria}

Patients who met the following inclusion criteria were recruited: 1) aged 18 years or over; 2) being conscious and not having serious complications such as mental disorders; and 3) able to read in Persian.

\section{Participant recruitment}

The doctors in the teaching hospitals in Cardiology, Dermatology, Gastroenterology, and Internal Medicine recruited the patients with chronic diseases at discharge and the inpatients with stable conditions. The questionnaires were handed to the patients directly by the researchers. The aim of the study, its voluntary nature, and assurance about anonymity of results in any resulted publications were orally explained by the researchers. 
Informed consent was sought before distributing the questionnaire. Data collection was conducted during March 1 to August 1, 2020.

\section{Step 3. Data analysis}

\section{Exploratory and confirmatory factor analysis}

To evaluate the construct validity, the exploratory factor analysis (EFA) was conducted in SPSS version 19. Due to the significant correlation between items, the Promax rotation was used to extract the latent factors.

Eigenvalue $\geq 1$ was used to identify the factors. Explained variance of each factor and cumulative explained variance for the entire survey were obtained. The Kaiser-Meyer-Olkin (KMO) index was checked for proportion of variance in the variables that might be caused by the underlying factors. Bartlett's Test of Sphericity was conducted to check redundancy between the variables. If an item had a Communality value below 0.5 , it would be deleted [15].

Confirmatory factor analysis (CFA) with maximum likelihood was applied to evaluate the goodness of fit of the extracted structure by EFA. The goodness of fit indices such as Comparative Fit Index (CFI $\geq 0.90)$, TuckerLewis Index ( $T L I \geq 0.90)$, Root Mean Square Error of Approximation (RMSEA $\leq 0.06$ ), Chi-square/Degree of Freedom (CMIN/DF $\leq 3$ ), and Goodness of Fit Index (GFI $\geq 0.90)$ were checked [18]. Also, factor loading for each item was examined. Analysis was performed in Amos version 19.

\section{The convergent and discriminant validity and internal reliability}

Convergent and discriminant validity are two aspects of construct validity. The convergent validity, evaluated through average variance extracted (AVE), and construct reliability (CR), ensures the relationship between two theoretically related factors of a construct. The CR and AVE for the factors of a construct should exceed 0.70 and 0.50 respectively. Discriminant validity, evaluated through maximum shared squared variance (MSV), and average shared square variance (ASV), ensures no relationship between two theoretically unrelated factors. For discriminant validity, the AVE value must be higher than two MSV and ASV values [19]. Also, the internal reliability was assessed by Cronbach's alpha coefficient with value higher than 0.7 indicating acceptable level of reliability [20].

\section{Comparison of the mean value of the factors between different groups}

The criteria of sex, computer literacy and education level were used for demographic groupings. Shapiro-Wilk test was conducted to assess the normality of distribution of data. One-way ANOVA test was conducted to compare means of each factor in different education levels. Independent samples t-test and Mann-Whitney $U$ test was conducted to compare different demographic group's performance on each factor.

\section{Results}

Three hundred patients with chronic diseases were invited, 289 (96.33\%) participated with informed consent, and returned the questionnaire responses. The mean age of the respondents was $44.76 \pm 5.85$ years (range: 36 64 years). The majority were females $(53.8 \%, n=155)$, and most had no ICDL certificate $(84.78 \%, n=245)$. Women had significantly higher scores than men in HIN (Women: $3.10 \pm .66$; Men: $2.78 \pm 0.52, p<=0.001$ ) and 


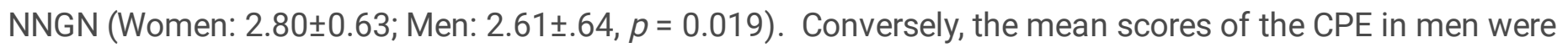
significantly higher than that in women (Women: $3.54 \pm 0.63$; Men: $3.56 \pm .65, p=0.026$ ). There were a positive association between level of education and CIEE, PMI, and CPE. The mean scores of the HIN, CIEE, PMI, and CPE factors were significantly higher in people who had ICDL certificates than otherwise (see Table 3 ).

Table 3. Comparison of the mean scores of each factor between groups 


\begin{tabular}{|c|c|c|c|c|c|c|c|c|c|c|c|}
\hline \multirow[t]{2}{*}{ Factors } & \multirow[t]{2}{*}{$\begin{array}{l}\text { Mean } \\
\text { (S.D.) }\end{array}$} & \multicolumn{2}{|c|}{ Gender } & \multirow[t]{2}{*}{$\begin{array}{l}p- \\
\text { value }\end{array}$} & \multicolumn{3}{|c|}{ Education level } & \multirow[t]{2}{*}{$p$-value } & \multicolumn{2}{|c|}{$\begin{array}{l}\text { ICDL } \\
\text { Certificate }\end{array}$} & \multirow[t]{2}{*}{$P$-value } \\
\hline & & $\begin{array}{l}\mathrm{M} \\
(88)\end{array}$ & $\begin{array}{l}F \\
(201)\end{array}$ & & $\mathrm{D}^{+}$ & $\mathrm{B}^{\neq}$ & $\mathrm{H}^{\S}$ & & $\begin{array}{l}\text { Yes } \\
\text { (44) }\end{array}$ & $\begin{array}{l}\text { No } \\
(245)\end{array}$ & \\
\hline \multirow[t]{3}{*}{ HIN } & $\begin{array}{l}3.00 \\
(0.58)\end{array}$ & 2.78 & 3.10 & $\begin{array}{l}<= \\
.001^{*}\end{array}$ & 3.01 & 3 & 3.01 & $\begin{array}{l}\text { D-B } \\
(0.989)\end{array}$ & 3.12 & 2.96 & $0.035^{*}$ \\
\hline & & & & & & & & $\mathrm{D}-\mathrm{H}(1)$ & & & \\
\hline & & & & & & & & $\begin{array}{l}\text { B-H } \\
(0.990)\end{array}$ & & & \\
\hline \multirow[t]{3}{*}{ CA } & $\begin{array}{l}2.45 \\
(0.63)\end{array}$ & 2.39 & 2.47 & 0.331 & 2.50 & 2.49 & 2.38 & $\begin{array}{l}\text { D-B } \\
(0.999)\end{array}$ & 2.33 & 2.49 & 0.057 \\
\hline & & & & & & & & $\stackrel{\text { D- }}{\mathrm{H}}(0.444)$ & & & \\
\hline & & & & & & & & $\stackrel{\text { B- }}{\mathrm{H}}(0.379)$ & & & \\
\hline \multirow[t]{3}{*}{ CIEE } & $\begin{array}{l}3.22 \\
(0.57)\end{array}$ & 3.27 & 3.20 & 0.357 & 2.93 & 3.11 & 3.48 & $\begin{array}{l}\text { D-B } \\
(0.09)\end{array}$ & 3.48 & 3.13 & $<=0.001^{*}$ \\
\hline & & & & & & & & $\begin{array}{l}\text { D-H } \\
\left(<=.001^{\star}\right)\end{array}$ & & & \\
\hline & & & & & & & & $\begin{array}{l}\text { B-H } \\
\left(<=.001^{\star}\right)\end{array}$ & & & \\
\hline \multirow[t]{3}{*}{ PMI } & $\begin{array}{l}2.71 \\
(0.46)\end{array}$ & 2.70 & 2.72 & 0.811 & 2.59 & 2.72 & 2.78 & $\begin{array}{l}\text { D-B } \\
(0.174)\end{array}$ & 2.82 & 2.67 & $0.014^{*}$ \\
\hline & & & & & & & & $\begin{array}{l}\text { D-H } \\
\left(0.019^{*}\right)\end{array}$ & & & \\
\hline & & & & & & & & $\begin{array}{l}\text { B-H } \\
(0.593)\end{array}$ & & & \\
\hline \multirow[t]{3}{*}{ NNGN } & $\begin{array}{l}2.74 \\
(0.64)\end{array}$ & 2.61 & 2.80 & $0.019^{*}$ & 2.69 & 2.77 & 2.74 & $\begin{array}{l}\text { D-B } \\
(0.745)\end{array}$ & 2.80 & 2.72 & 0.353 \\
\hline & & & & & & & & $\begin{array}{l}\mathrm{D}- \\
\mathrm{H}(0.855)\end{array}$ & & & \\
\hline & & & & & & & & $\stackrel{\text { B- }}{\mathrm{H}}(0.966)$ & & & \\
\hline \multirow[t]{3}{*}{ RWD } & $\begin{array}{l}3.24 \\
(0.51)\end{array}$ & 3.22 & 3.24 & 0.756 & 3.26 & 3.27 & 3.20 & $\begin{array}{l}\text { D-B } \\
(0.994)\end{array}$ & 3.31 & 3.21 & 0.110 \\
\hline & & & & & & & & $\begin{array}{l}\text { D-H } \\
(0.740)\end{array}$ & & & \\
\hline & & & & & & & & $\stackrel{\text { B- }}{\mathrm{H}}(0.602)$ & & & \\
\hline CPE & $\begin{array}{l}3.48 \\
(0.63)\end{array}$ & 3.56 & 3.54 & $0.026^{*}$ & 3.28 & 3.45 & 3.62 & $\begin{array}{l}\text { D-B } \\
(0.267)\end{array}$ & 3.61 & 3.43 & $0.021^{*}$ \\
\hline
\end{tabular}




\begin{tabular}{|c|c|c|c|c|c|c|c|c|c|c|c|}
\hline & & & & & & & & $\begin{array}{l}\text { D- } \\
\mathrm{H}\left(0.003^{*}\right) \\
\mathrm{B}-\mathrm{H} \\
(0.074)\end{array}$ & & & \\
\hline \multirow[t]{3}{*}{ IPC } & $\begin{array}{l}2.65 \\
(0.74)\end{array}$ & 2.73 & 2.62 & 0.230 & 2.75 & 2.63 & 2.62 & $\begin{array}{l}\text { D-B } \\
(0.558)\end{array}$ & 2.68 & 2.65 & 0.746 \\
\hline & & & & & & & & $\begin{array}{l}\text { D- } \\
\mathrm{H}(0.439)\end{array}$ & & & \\
\hline & & & & & & & & $\begin{array}{l}\mathrm{B}- \\
\mathrm{H}(0.982)\end{array}$ & & & \\
\hline
\end{tabular}

*: Statistically significant difference in mean; D: Diploma; B: Bachelor; H: Master of science and higher.

The KMO value was 0.79 , suggesting that certain proportion of variance in digital health readiness is caused by the underlying factors. Bartlett's test of sphericity was statistically significant (sig < 0.001$)$, suggesting minimal redundancy between the factors, thus the data set were suitable for EFA. The communality of items was higher than 0.5 (ranged from 0.550 to 0.877 ), suggesting that each item loaded significantly only on one factor. The factor loading of each item was $\geq 0.6$, except for item 8 (0.584) (see Table 4). This suggests high relevance of the items in explaining the corresponding factor. Eight factors were extracted by EFA, which explained $69 \%$ of the total variance. In descending order of the variance explained, the factors were $\mathrm{HIN}=20.34, \mathrm{CA}=12.68, \mathrm{CIEE}=$ 9.35, $\mathrm{PMI}=7.08, \mathrm{NNGN}=6.08, \mathrm{RWD}=5.08, \mathrm{CPE}=4.72$, and $\mathrm{IPC}=4.07 \%$, respectively.

Table 4. Factor loadings of each item and variance explained by each factor. 


\begin{tabular}{|c|c|c|c|}
\hline factor & Items & $\begin{array}{l}\text { Factor } \\
\text { loading }\end{array}$ & $\begin{array}{l}\% \text { of } \\
\text { Variance }\end{array}$ \\
\hline 1 & $\begin{array}{l}\text { Q24: I would use the internet to look up things so that I } \\
\text { wouldn't worry about them anymore. }\end{array}$ & 0.769 & \multirow[t]{5}{*}{20.34} \\
\hline \multirow{2}{*}{$\begin{array}{l}\text { Health Information } \\
\text { Need }\end{array}$} & $\begin{array}{l}\text { Q25: I would use the internet to look up information about } \\
\text { herbs and/or supplements }\end{array}$ & 0.826 & \\
\hline & Q26: I would use the internet to look up symptoms. & 0.857 & \\
\hline \multirow{2}{*}{$(\mathrm{HIN})$} & $\begin{array}{l}\text { Q27: I would use the internet to search for information about } \\
\text { my health. }\end{array}$ & 0.831 & \\
\hline & $\begin{array}{l}\text { Q28: I would use the internet to find information about } \\
\text { medications. }\end{array}$ & 0.842 & \\
\hline \multirow[t]{2}{*}{2} & Q15: Using the computer is boring for me. & 0.827 & \multirow[t]{4}{*}{12.68} \\
\hline & $\begin{array}{l}\text { Q21: When I use the Internet, I would get frustrated and tired } \\
\text { with the amount of information I found about health. }\end{array}$ & 0.706 & \\
\hline \multirow{2}{*}{$\begin{array}{l}\text { Computer Anxiety } \\
\text { (CA) }\end{array}$} & $\begin{array}{l}\text { Q22: I think that searching for information would be } \\
\text { stressful. }\end{array}$ & 0.749 & \\
\hline & $\begin{array}{l}\text { Q23: If I went on the internet, I would find sorting through } \\
\text { information to be too time consuming. }\end{array}$ & 0.769 & \\
\hline \multirow{4}{*}{$\begin{array}{l}3 \\
\text { Computer/Internet } \\
\text { Experience, Expertise } \\
\text { (CIEE) }\end{array}$} & $\begin{array}{l}\text { Q14: When I use a computer, I would be able to figure out } \\
\text { most problems that I might run into. }\end{array}$ & 0.642 & \multirow[t]{4}{*}{9.35} \\
\hline & $\begin{array}{l}\text { Q16: When I use a computer, I would have access to the } \\
\text { internet. }\end{array}$ & 0.752 & \\
\hline & Q17: Using the internet is easy for me. & 0.716 & \\
\hline & Q18: Using the email service is easy for me. & 0.799 & \\
\hline \multirow[t]{2}{*}{4} & Q5: I trust the internet as a source for health information. & 0.675 & \multirow[t]{5}{*}{7.08} \\
\hline & $\begin{array}{l}\text { Q8: Looking up health concerns on the internet is more } \\
\text { convenient for me than contacting a doctor's office. }\end{array}$ & 0.585 & \\
\hline $\begin{array}{l}\text { Preferred Mode of } \\
\text { Interaction }\end{array}$ & Q9: I prefer calling my doctor's office to emailing them. & 0.664 & \\
\hline \multirow[t]{2}{*}{ (PMI) } & $\begin{array}{l}\text { Q10: I would email my doctor because it is easier than going } \\
\text { to the office. }\end{array}$ & 0.732 & \\
\hline & $\begin{array}{l}\text { Q11: Looking up information online about medications is } \\
\text { easier than asking my doctor. }\end{array}$ & 0.620 & \\
\hline 5 & Q2: People today want to know more about their health. & 0.859 & \multirow[t]{3}{*}{6.08} \\
\hline \multirow{2}{*}{$\begin{array}{l}\text { No News is Good } \\
\text { News (NNGN) }\end{array}$} & $\begin{array}{l}\text { Q3: Regarding my health, I agree with the statement "No } \\
\text { news is good news." }\end{array}$ & 0.802 & \\
\hline & $\begin{array}{l}\text { Q6: I am concerned about what I might find on the Internet } \\
\text { about my health problems. }\end{array}$ & 0.841 & \\
\hline 6 & Q1: I let my doctor to control the details of my health. & 0.738 & 5.08 \\
\hline Relationship with & Q4: Doctors are my most trusted source of health & 0.875 & \\
\hline
\end{tabular}

Page 12/19 


\begin{tabular}{|llll|}
\hline Doctor (RWD) & information. & & \\
& $\begin{array}{l}\text { Q7: When I have a health concern, my first step is to contact } \\
\text { my doctor's office. }\end{array}$ & 0.787 & \\
\hline 7 & Q12: I go online using my cell phone. & 0.826 & 4.72 \\
\hline $\begin{array}{l}\text { Cell Phone Expertise } \\
\text { (CPE) }\end{array}$ & Q13: I use my cell phone to text people almost every day. & 0.717 & \\
\hline 8 & $\begin{array}{l}\text { Q19: When I use the internet, I would be very concerned } \\
\text { about giving any personal information. }\end{array}$ & 0.909 & 4.07 \\
\hline $\begin{array}{l}\text { Internet Privacy } \\
\text { Concerns (IPC) }\end{array}$ & $\begin{array}{l}\text { Q20: When I use the internet, I would be concerned it would } \\
\text { lead to invasions of my privacy. }\end{array}$ & 0.899 & \\
\hline
\end{tabular}

Confirmatory factor analysis confirmed the goodness-of-fit of the factor structure with all of the goodness of fit indices on the favorable threshold (see Figure 1). The CFI, TLI, IFI, GFI, and RMSEA indices were at the acceptable threshold $(\mathrm{CFI}=0.943, \mathrm{TLI}=0.931, \mathrm{IFI}=0.944, \mathrm{GFI}=0.893, \mathrm{RMSEA} \leq 0.06, \chi 2 / \mathrm{df}=1.625, \mathrm{df}=292, P$ value $\leq$ 0.001).

One item (Item 9) was removed from the tool due to low factor loading (0.39). After deleting this item, the internal consistency as assessed by the Cronbach's alpha coefficient achieved the satisfactory level of 0.729 (see Table 5). The Cronbach's alpha coefficient for each factor, including RWD $=0.750, \mathrm{NNGN}=0.807, \mathrm{PMI}=$ $0.733, \mathrm{CPE}=0.747, \mathrm{CIEE}=0.770, \mathrm{CA}=0.813, \mathrm{IPC}=0.880$, and $\mathrm{HIN}=0.897$, was above 0.70 ; therefore the internal consistency of the questionnaire was optimal. The results of convergent and discriminant validity, internal consistency, and CR are presented in Table 5. The AVE for all factors is higher than 0.50 except for PMI (0.427) and CIEE (0.463). The CR for factors were higher than 0.7 and ranged from 0.740 to 0.892 , which was acceptable. Fornell \& Larcker (1981) stated that if the AVE of a factor is less than 0.5 but its composite reliability is higher than 0.6 , the convergent validity of the construct is adequate. ${ }^{20}$ Therefore, the AVE and CR values approves the convergent validity of PRE-HIT instrument. Also, the MSV and ASV values for each factor were lower than AVE values; therefore, the divergent validity of all factors was acceptable.

Table 5. Internal consistency, convergent and discriminant validity, and CR values 


\begin{tabular}{|c|c|c|c|c|c|c|c|c|}
\hline Factor & Items & $\begin{array}{l}\text { Cronbach's Alpha if } \\
\text { Item Deleted }\end{array}$ & $\begin{array}{l}\text { Item-Total } \\
\text { Correlation }\end{array}$ & $\begin{array}{l}\text { Cronbach's } \\
\text { Alpha }\end{array}$ & CR & AVE & MSV & ASV \\
\hline 1 & Q24 & 0.888 & 0.685 & \multirow[t]{5}{*}{0.897} & 0.892 & 0.625 & 0.292 & 0.076 \\
\hline \multirow[t]{4}{*}{ HIN } & Q25 & 0.873 & 0.755 & & & & & \\
\hline & Q26 & 0.863 & 0.803 & & & & & \\
\hline & Q27 & 0.873 & 0.754 & & & & & \\
\hline & Q28 & 0.875 & 0.748 & & & & & \\
\hline 2 & Q15 & 0.768 & 0.633 & \multirow[t]{4}{*}{0.813} & 0.802 & 0.506 & 0.191 & 0.098 \\
\hline \multirow[t]{3}{*}{ CA } & Q21 & 0.776 & 0.610 & & & & & \\
\hline & Q22 & 0.748 & 0.670 & & & & & \\
\hline & Q23 & 0.770 & 0.623 & & & & & \\
\hline 3 & Q14 & 0.765 & 0.489 & \multirow[t]{4}{*}{0.770} & 0.767 & 0.463 & 0.404 & 0.101 \\
\hline \multirow[t]{3}{*}{ CIEE } & Q16 & 0.708 & 0.591 & & & & & \\
\hline & Q17 & 0.710 & 0.608 & & & & & \\
\hline & Q18 & 0.675 & 0.647 & & & & & \\
\hline 4 & Q5 & 0.676 & 0.527 & \multirow[t]{5}{*}{0.733} & 0.740 & 0.427 & 0.292 & 0.089 \\
\hline \multirow[t]{4}{*}{ PMI } & Q8 & 0.672 & 0.533 & & & & & \\
\hline & Q9 & 0.728 & 0.377 & & & & & \\
\hline & Q10 & 0.693 & 0.484 & & & & & \\
\hline & Q11 & 0.661 & 0.559 & & & & & \\
\hline 5 & Q2 & 0.720 & 0.682 & \multirow[t]{3}{*}{0.807} & 0.814 & 0.595 & 0.109 & 0.028 \\
\hline \multirow[t]{2}{*}{ NNGN } & Q3 & 0.781 & 0.611 & & & & & \\
\hline & Q6 & 0.703 & 0.696 & & & & & \\
\hline 6 & Q1 & 0.737 & 0.516 & \multirow[t]{3}{*}{0.750} & 0.767 & 0.532 & 0.028 & 0.012 \\
\hline \multirow[t]{2}{*}{ RWD } & Q4 & 0.532 & 0.685 & & & & & \\
\hline & Q7 & 0.697 & 0.554 & & & & & \\
\hline 7 & Q12 & - & 0.608 & \multirow[t]{2}{*}{0.747} & 0.756 & 0.608 & 0.404 & 0.123 \\
\hline CPE & Q13 & - & 0.608 & & & & & \\
\hline 8 & Q19 & - & 0.786 & \multirow[t]{2}{*}{0.880} & 0.887 & 0.799 & 0.191 & 0.042 \\
\hline IPC & Q20 & - & 0.786 & & & & & \\
\hline
\end{tabular}


CR: construct reliability; AVE: average variance extracted; MSV: maximum shared squared variance; ASV: average shared square variance.

\section{Discussion}

This study developed and validated the Persian version of the PRE-HIT in measuring digital health readiness of Iranian patients with chronic illness. The instrument achieved satisfactory level of reliability and validity, and factor loading. In addition, the number and structure of the extracted factors were in accordance with Koopman's study [9]. Thus the Persian version of the PRE-HIT is valid to measure readiness of Iranian patients in engaging with digital health.

There are mixed findings in comparing computer literacy level between men and women. Women had significantly higher level of health information needs than men, as found by Stewart et al. (2004) in 635 Canadian adults. Their results showed that women were keener to seek information on angina (1.77 times) and blood pressure (1.57 times) [21]. Previous studies also found that women were more likely than men to use the internet to access health information $[22,23]$. Also, women with chronic medical conditions were more likely to search health information [24].

Joiner finds that computer use efficiency in women is lower than in men [25]. This may explain the higher level of computer anxiety we observed in women than in men, although not statistically significant. Dyck et al. reached the similar finding [26]. Conversely computer/internet experience and IT expertise were higher in men than in women, which is consistent with the previous findings $[25,27]$. However, this gender difference was not supported by Samadbeik et al [28]. No difference was found in "relationship with doctor" across educational levels and gender, which is in agreement with the finding of Cooper-Patrick [29].

Both male and female patients held moderate level of privacy concerns, which is different from the finding of Youn that females had a higher level of privacy concerns [30]. Similar with Atherton et al (2012) and Hanauer et al (2009) [4, 31], this study finds that the level of digital readiness were equally high in men $(\mathrm{mean}=2.86)$ and women $($ mean $=2.94)$.

\section{Conclusion}

The Persian version of the PRE-HIT is a reliable and valid tool to evaluate and compare the level of digital readiness of patients with chronic illness. This tool is useful for policy makers and healthcare organisations to use to measure patients' digital readiness to inform options and strategies to introducing consumer digital health solutions for patient self-management of disease.

\section{Declarations}

\section{Ethics approval and consent to participate:}

Ethics approval and consent to participate was granted by the relevant authority, the Research Deputy, in the teaching hospitals of Tehran University of Medical Sciences. All methods in the manuscript were carried out in accordance with relevant guidelines and regulations and also informed consent was obtained from all participants of the study.

Page 15/19 
Consent for publication:

Not applicable.

\section{Availability of data and materials:}

Data available on request from the authors.

\section{Competing interests:}

The authors declared no conflicts of interest with respect to the research, authorship, and publication of this article.

\section{Funding:}

This work was supported by the Mazandaran University of Medical Sciences with ethical code IR.MAZUMS.REC.1399.355.

\section{Authors' contributions:}

SB and RS contributed to the conception and design of the work. EGH, SKH, ZJ, and AY contributed to the acquisition of the data. SB analysed data and SB, PU, and RS were involved in the interpretation of the data. All authors drafted the initial version of the manuscript. PU, SB, and RS provided critical feedback to revise and improve the manuscript. Finally, all authors gave their final approval for submission of this manuscript.

\section{Acknowledgements:}

The authors would like to thank the patients that participated in this study.

\section{References}

1. Calton B, Abedini N, Fratkin M. Telemedicine in the time of coronavirus. J Pain Symptom Manage. 2020; 60(1):e12-e14. https://doi.org/10.1016/j.jpainsymman.2020.03.019

2. Jacobs RJ, Iqbal H, Rana AM, et al. Predictors of osteopathic medical students' readiness to use health information technology. J Osteopath Med. 2017; 117(12):773-781. https://doi.org/10.7556/jaoa.2017.149.

3. Yusif S, Hafeez-Baig A, Soar J. e-Health readiness assessment factors and measuring tools: A systematic review. Int J Med Inform. 2017; 107:56-64. https://doi.org/10.1016/j.ijmedinf.2017.08.006.

4. Atherton H, Sawmynaden P, Sheikh A, et al. Email for clinical communication between patients/caregivers and healthcare professionals. Cochrane Database Syst Rev. 2012; (11). https://doi.org/10.1002/14651858.CD007978.pub2.

5. Demiris G, Afrin LB, Speedie S, et al. Patient-centered applications: use of information technology to promote disease management and wellness. A white paper by the AMIA knowledge in motion working group. JAMIA. 2008; 15(1):8-13. https://doi.org/10.1197/jamia.M2492.

6. Leung L, Chen C. E-health/m-health adoption and lifestyle improvements: Exploring the roles of technology readiness, the expectation-confirmation model, and health-related information activities. Telecomm Policy. 2019; 43(6):563-575. https://doi.org/10.1016/j.telpol.2019.01.005. 
7. Kayser L, Rossen S, Karnoe A, et al. Development of the multidimensional readiness and enablement index for health technology (READHY) tool to measure individuals' health technology readiness: initial testing in a cancer rehabilitation setting. J Med Internet Res. 2019; 21(2):e10377. doi: 10.2196/10377.

8. Parasuraman A, Colby CL. An updated and streamlined technology readiness index: TRI 2.0. J Serv Res. 2015; 18(1):59-74. https://doi.org/10.1177/1094670514539730.

9. Koopman RJ, Petroski GF, Canfield SM, et al. Development of the PRE-HIT instrument: patient readiness to engage in health information technology. BMC Fam Pract. 2014; 15(1):1-9. doi:10.1186/1471-2296-15-18.

10. Hirani SP, Rixon L, Beynon M, et al. Quantifying beliefs regarding telehealth: development of the whole systems demonstrator service user technology acceptability questionnaire. J Telemed Telecare. 2017; 23(4):460-469. https://doi.org/10.1177/1357633X16649531.

11. Jones R. Development of a questionnaire and cross-sectional survey of patient ehealth readiness and ehealth inequalities. Med 20. 2013; 2(2). doi: 10.2196/med20.2559.

12. Norman CD, Skinner HA. eHEALS: the eHealth literacy scale. JMIR. 2006; 8(4):e27. doi: 10.2196/jmir.8.4.e27.

13. Van der Vaart R, Van Deursen AJ, Drossaert CH, et al. Does the eHealth Literacy Scale (eHEALS) measure what it intends to measure? Validation of a Dutch version of the eHEALS in two adult populations. JMIR. 2011; 13(4):e86. doi: 10.2196/jmir.1840.

14. Zamanzadeh V, Ghahramanian A, Rassouli M, et al. Design and implementation content validity study: development of an instrument for measuring patient-centered communication. J Caring Sci. 2015; 4(2):165. doi: $10.15171 /$ jcs.2015.017.

15. Ghazisaeedi M, Mahmoodi H, Arpaci I, et al. Validity, Reliability, and Optimal Cut off Scores of the WHO-5, PHQ-9, and PHQ-2 to Screen Depression Among University Students in Iran. Int J Ment Health Addict. 2021; 1-10. https://doi.org/10.1007/s11469-021-00483-5.

16. Lawshe CH. A quantitative approach to content validity. Pers Psychol. 1975; 28(4):563-575. https://doi.org/10.1111/j.1744-6570.1975.tb01393.x.

17. Hatamipour K, Rassouli M, Yaghmaie F, et al. Development and psychometrics of a 'spiritual needs assessment scale of patients with cancer': A mixed exploratory study. Int J Cancer Manag. 2018; 11(1). DOI : 10.5812/ijcm.10083.

18. Schreiber JB, Nora A, Stage FK, et al. Reporting structural equation modeling and confirmatory factor analysis results: A review. J Educ Res. 2006; 99(6):323-338. https://doi.org/10.3200/JOER.99.6.323-338.

19. Nikkhah M, Heravi-Karimooi M, Montazeri A, et al. Psychometric properties the Iranian version of older People's quality of life questionnaire (OPQOL). Health Qual Life Outcomes. 2018;16(1):1-10. https://doi.org/10.1186/s12955-018-1002-z.

20. Chakraborty P, Vissoci JR, Muhumuza C, et al. Validity of the Personal Impact of Epilepsy Scale (PIES) in patients with epilepsy in Uganda. Epilepsy Behav. 2021 Jan 1;114:107303.

https://doi.org/10.1016/j.yebeh.2020.107303.

21. Stewart DE, Abbey SE, Shnek ZM, et al. Gender differences in health information needs and decisional preferences in patients recovering from an acute ischemic coronary event. Psychosom Med. 2004; 66(1):4248. doi:10.1097/01.PSY.0000107006.83260.12. 
22. Bidmon S, Terlutter R. Gender differences in searching for health information on the internet and the virtual patient-physician relationship in Germany: exploratory results on how men and women differ and why. JMIR. 2015; 17(6):e4127. doi: 10.2196/jmir.4127.

23. Rice RE. Influences, usage, and outcomes of Internet health information searching: multivariate results from the Pew surveys. Int J Med Inform. 2006; 75(1):8-28. https://doi.org/10.1016/j.jjmedinf.2005.07.032.

24. Renahy E, Parizot I, Chauvin P. Determinants of the frequency of online health information seeking: results of a web-based survey conducted in France in 2007. Inform Health Soc Care. 2010; 35(1):25-39. DOI : 10.3109/17538150903358784.

25. Joiner R, Gavin J, Duffield J, et al. Gender, Internet identification, and Internet anxiety: Correlates of Internet use. CyberPsychology \& Behavior. 2005; 8(4):371-378. https://doi.org/10.1089/cpb.2005.8.371.

26. Dyck JL, Smither JA-A. Age differences in computer anxiety: The role of computer experience, gender and education. Journal of educational computing research. 1994; 10(3):239-248. https://doi.org/10.2190/E79UVCRC-EL4E-HRYV.

27. Joiner R, Gavin J, Brosnan M, et al. Gender, internet experience, internet identification, and internet anxiety: a ten-year followup. Cyberpsychol Behav Soc Netw. 2012; 15(7):370-372.

https://doi.org/10.1089/cyber.2012.0033.

28. Samadbeik M, Garavand A, Saremian M, et al. Readiness of patients with chronic diseases to use health information technology: An experience of a developing country. Shiraz E Med J. 2018; 19(10). DOI : 10.5812/semj.65797.

29. Cooper-Patrick L, Gallo JJ, Gonzales JJ, et al. Race, gender, and partnership in the patient-physician relationship. JAMA. 1999; 282(6):583-589. doi:10.1001/jama.282.6.583.

30. Youn S, Hall K. Gender and online privacy among teens: Risk perception, privacy concerns, and protection behaviors. Cyberpsychology \& behavior. 2008; 11(6):763-765. https://doi.org/10.1089/cpb.2007.0240.

31. Hanauer DA, Wentzell K, Laffel N, et al. Computerized Automated Reminder Diabetes System (CARDS): email and SMS cell phone text messaging reminders to support diabetes management. Diabetes Technol Ther. 2009; 11(2):99-106. https://doi.org/10.1089/dia.2008.0022.

\section{Figures}




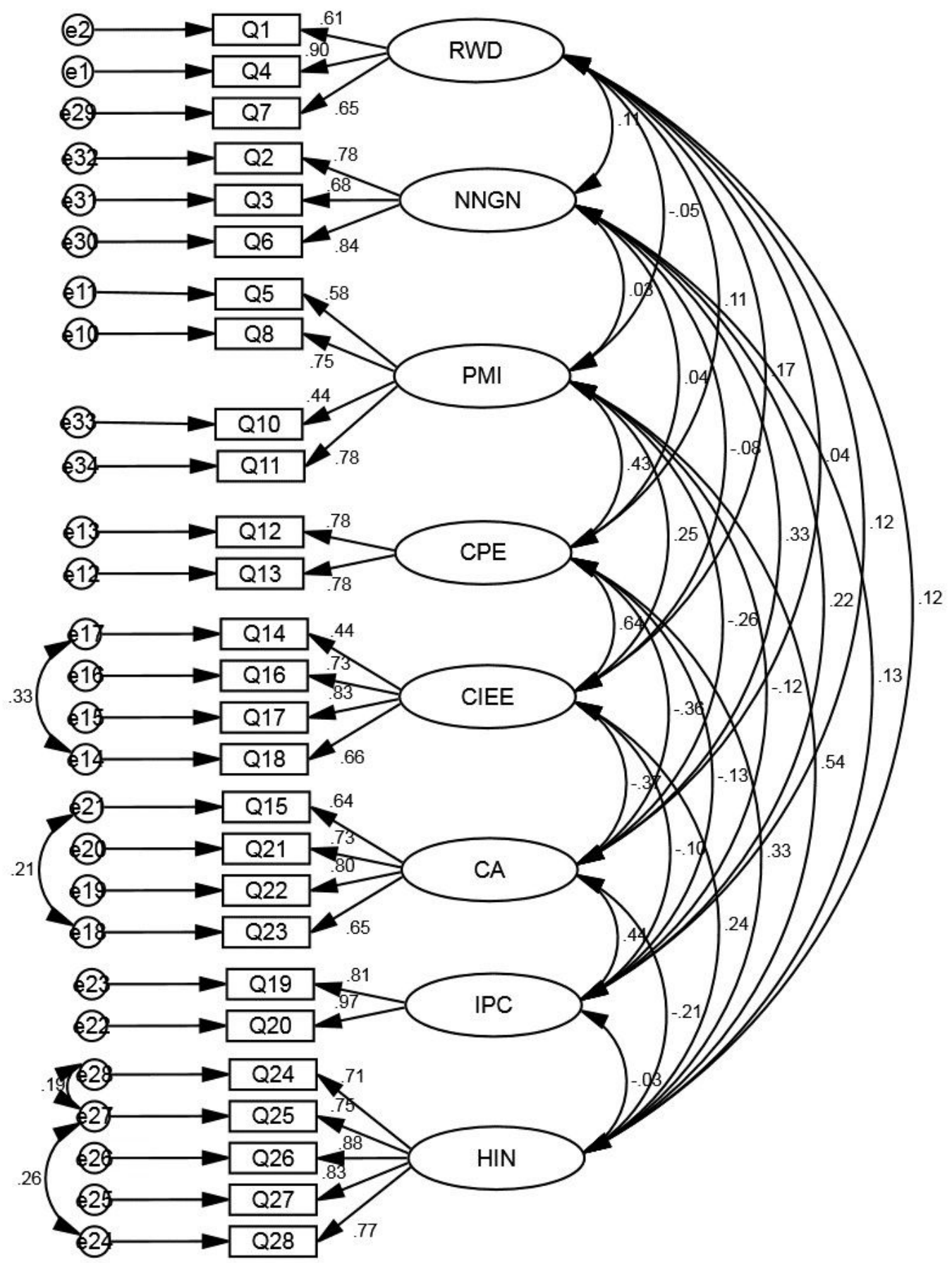

Figure 1

The final fitted model by confirmatory factor analysis 